\title{
Corporate Profitability and Shareholder Meeting Participation in Italian Listed Companies
}

\author{
Giuseppe Ianniello ${ }^{1} \&$ Alessandra Stefanoni ${ }^{1}$ \\ ${ }^{1}$ University of Tuscia, Viterbo, Italy \\ Correspondence: Alessandra Stefanoni, Department of Economics, Engineering, Society and Business \\ Organization, University of Tuscia, Viterbo Italy. E-mail: stefanoniale@unitus.it \\ Received: November 25, 2021 \\ Accepted: January 15, 2022 \\ Online Published: January 25, 2022 \\ doi:10.5539/ijbm.v17n3p26 \\ URL: https://doi.org/10.5539/ijbm.v17n3p26
}

\begin{abstract}
This paper intends to investigate the relationship between the attendance of annual general meetings (AGMs) and company performance in terms of profitability. In particular, it is intended to highlight some elements that can be interpreted as constituting attendance at the shareholder meetings, for example, the number of shareholders present at the shareholder meeting, the share of authorized capital attending the shareholder meeting, and the duration of the shareholder meeting. Following this analysis, attention is devoted to the relationship between corporate performance and shareholder meeting participation (one of the possible governance mechanisms available to monitor the activity carried out by company management). We analyse the AGMs convened for the adoption of financial statements. Empirically, the study uses the minutes of the meetings of a sample of Italian listed companies held in 2017 and 2018 on the occasion of the adoption of financial statements for the 2016 and 2017 fiscal periods, respectively. The main results show a positive relationship between the share of authorized capital attending annual shareholder meetings and the level of corporate profitability of Italian listed companies.
\end{abstract}

Keywords: Annual general meeting (AGM), Shareholder meeting, corporate profitability, shareholder democracy, corporate governance

\section{Introduction}

The main research question addressed in this paper concerns the relationship between attendance at annual shareholder meetings and company performance in terms of profitability. Preliminary to this issue, there is the question of "shareholder democracy" and the possible role that stockholders can play in the context of business decisions influencing economic performance. A study carried out by the Belgian consultancy company Deminor, on behalf of the Association of British Insurers, highlights the weakness of the democratic participation of shareholders in the governance of large European listed companies through various forms of deviation from the "one vote per share" principle (The Economist, 2005, p. 60). As part of this debate, the European Union issued the 2007/36/EC Directive implemented in Italy with Legislative Decree No. 27/2010 aimed at encouraging the participation of shareholders in exercising voting rights during shareholder meetings of listed companies. However, there is not unanimous support for the idea that the democratic principle of "one vote per share" is necessary; at the international level, there are a significant number of cases of "undemocratic" management of large companies due to restrictions on voting rights, the existence of a group of shareholders that exercises legal or de facto control, and the passive behaviour of some investment funds (The Economist, 2017, p. 4). In addition, it should be noted that the principle currently defined as democratic (one vote per share) has historically been defined as a shift towards a "plutocratic" principle in the 19th century to replace the genuine democratic principle that can be summed up in the expression "one vote per person" (Danlavy, 2006). In essence, in modern language, it is assumed that plutocratic systems are democratic. The logic of this system is to tie cash flow rights to voting rights. Implicit in this approach is that those who are most at risk have an incentive to make effective and efficient decisions in economic terms, considering social and environmental requirements and constraints in the current context. Hence, the logic of giving more power to those who invest the most in terms of capital: that is, the principle of "one vote per share". However, especially in cases of business crises or when business risk manifests itself negatively, the adverse economic effects fall on other stakeholders, for example, employees, suppliers, and public administration (Catturi, 2019). Although it cannot be demonstrated by conclusive evidence, 
there is no guarantee that those who risk more will make more appropriate decisions for business survival while respecting the economic and financial equilibrium. In addition, legislation, both in Italy and in other institutional contexts, provides mechanisms through which it is permitted to have decision-making power that is greater than the level of equity investment, which represents a deviation from the modern democratic principle of "one vote per share". This is intended to support a group of controlling shareholders by encouraging their continued existence in corporate governance over time. In this way, a group of shareholders permanently interested in business management could help to mitigate the problem that stems from the separation of ownership and control, as historically identified in the 1930s by Bearle and Means (1933), in terms of possible opportunistic behaviour by management. In Italy, where, in general, ownership is not divided between many shareholders, this problem manifests itself in the conflict between majority and minority shareholders.

In this context, the purpose of this paper is to present a descriptive analysis of certain characteristics relating to the way in which shareholder meetings are held in Italian listed companies. In particular, it is intended to highlight some elements that can be interpreted as attendance in the shareholder meeting itself, for example, the number of shareholders present at the shareholder meeting, the share capital represented at the shareholder meeting, and the duration of the shareholders' meeting. The focus will then be on the relationship between company economic performance and attendance at the annual shareholder meeting convened for approval of the financial statements. This analysis helps to explain the potential relationship between corporate economic results and shareholder participation, one of the governance mechanisms available to monitor the activity carried out by company management. This issue has recently been proposed at the European institutional level in the Directive 2017/828/EU (Shareholders' Directive), adopted in Italy with the Legislative Decree No. 49/2019, which considers that the involvement of shareholders in the corporate governance of listed companies "is one of the levers that can help improve the financial and non-financial performance of companies, including as regards environmental, social and governance factors, in particular as referred to in the Principles for Responsible Investment, supported by the United Nations". In this research, in particular, we intend to analyse whether attendance at shareholder meetings is somehow associated with company profitability.

Empirically, the analysis uses the minutes of the annual general meetings (AGMs) of a sample of Italian listed companies that were held in 2017 and 2018 when the financial statements for the 2016 and 2017 fiscal periods, respectively, were approved.

The main results show a positive relationship between the share capital equity present at AGMs and the level of corporate profitability of Italian listed companies. In addition, the study highlighted some characteristics of how AGMs are conducted, including, for example, the number of shareholders attending, the share of equity represented, and the duration of the AGM.

The paper continues as follows. After the second section focuses on the Italian regulatory context, the third section references the literature and provides argument that support our research hypotheses. The fourth section is dedicated to empirical research, while the fifth section show the research results followed by discussion. In the last section, there are the conclusions of the paper and its possible future developments.

\section{Regulatory Framework}

Shareholder meetings are deliberative collegiate bodies of listed companies. They form and express corporate determination, which is then implemented by corporate management. The role and power of the AGM are ruled by the Civil Code (C.C.) and the Consolidated Text on Finance (TUF) (art. 125-bis and ss. TUF). The TUF rules on shareholder meetings mainly stem from the implementation of Directive 2007/36/EC aimed at encouraging the participation of shareholders in corporate decisions and the exercise of voting rights, including cross-border voting rights, by minority and foreign shareholders. The aim of the provisions is to make the transparency of pre-meeting information as effective as possible and to simplify the right to vote and to speak at AGMs.

Shareholder meetings may take place in an "ordinary or extraordinary" format, depending on the matters subject to decision and approval (art. 2363 C.C.). The organ is always the same; only the rules differ depending on whether the meeting to which shareholders are summoned is ordinary or extraordinary.

Whenever a shareholder meeting is convened, the minutes of the shareholder resolutions shall be drawn up. This document summarizes the decisions made at the AGM on certain matters relating to corporate management. In the case of an ordinary meeting, as required by art. 2375 C.C., the minutes shall be a written document to be signed by the President and the Secretary, the latter not necessarily a notary. The minutes must be drawn up "within the time necessary for the timely execution of the obligations to deposit or publish" (art. 2375 C.C.). In that regard, article 10 of the Directive does not state whether, in light of the particular circumstances of the case, 125-quater, paragraph 2, TUF, recognizes the company's website as a crucial tool to convey information. In this sense, within 
five days of the date of the shareholder meeting, the following information is available on the company's website: "a summary statement of the votes containing the number of shares represented at the shareholder meeting and the shares for which the vote was cast, the percentage of capital that these shares represent, as well as the number of votes in favour". However, "the minutes of the AGM referred to in article 2375 of the C. C. are still made available on the website within thirty days of the date of the meeting".

Shareholders "entitled to vote" have the right to attend the meeting (art. 2370 C.C.). In addition, association articles may provide for shares with limited voting rights or without voting rights. For the limited voting shareholder, the provisions of art. 2370 C.C. stipulate that he shall have the right to speak only at assemblies in which he is granted the right to vote. The ordinary meeting must be convened, according to art. 2364 C.C., at least once a year within the period provided for by the statutes and in any case not exceeding one hundred and twenty days, substantially at least once a year for the adoption of the annual financial statements.

As regards the notice of call, art. 125-bis TUF provides, in an absolute way, different convening times depending on the topic on which the meeting is called to deliberate (in addition to the ordinary period of 30 days, there are two shortened terms of 21 and 15 days for the meetings provided for in articles 2446, 2447 and 2487, C.C., respectively). That article also states that the notice of convening must indicate the so-called "record date" (art. 83-sexies TUF), i.e., the date by which the ownership of the shares must be recorded to legitimize the exercise of voting rights; therefore, any subsequent transfers of shares are to be considered irrelevant for the purposes of participation and the exercise of the vote in the shareholder meeting.

As provided by article 2350 C.C., moreover, "each share assigns the right to a proportional share of the net profits and equity resulting from liquidation". As a rule, equities have equal nominal value and equal rights (articles 2350 and 2351 C.C.). However, the company's articles of association may provide for different categories of shares (special shares), with diversified economic and administrative rights: increased voting power, which, by way of derogation from the "one share-one vote" principle, grants the shareholder the allocation of "an increased vote, up to a maximum of two, for each share belonging to the same investor for a continuous period of not less than twenty-four months from the date of registration" in a special list (art. 127 quinquies and 127 TUF sexies). This category of shares was introduced by the legislator in 2014 (Legislative Decree No. 91/2014) with the aim of promoting the listing of Italian companies and allowing the controlling shareholders of those companies or companies already listed to sell their shares, thus increasing the liquidity of the securities and maintaining, at the same time, a prominent role and weight within the company.

Regarding the rights of minority members, article 10 of the Directive does not apply to the rights of minority members. Article 126-bis TUF acknowledges that this category, which represents at least 1/40 of the share capital, to request, within certain time limits, "the integration of the subjects to be dealt with" on the agenda (with the exception of the items on which the shareholder meeting acts in accordance with the law).

Article 127b TUF states that those who have the right to vote are also entitled to ask questions during the AGM, which must be answered within the same meeting. In recent years, important simplifications have been introduced in the field of solicitation and collection of delegations, following the changes resulting from the implementation of EU Directives.

Article 135-novies TUF grants the voting partner "the right to delegate", even electronically, to a single representative and for a single meeting, with the right to designate one or more substitutes or to authorize the delegate to be replaced by a person of his choice. Consequently, companies with listed shares may use the figure of the "designated representative" within the meaning of art. 135-undecies TUF. The appointment must be indicated in the notice of call, together with information on how to confer the proxy vote.

Regarding the solicitation of powers, article 136 and ss. TUF state that this is the procedure by which a person (no longer just a professional intermediary who acts on behalf of the contracting authority as in the previous discipline) addresses "more than two hundred shareholders" (and not the generality of the same), requesting to join a specific proposal for a vote.

Overall, some of these regulatory aspects have been observed and taken from reading the minutes of the shareholder meetings of listed companies included in the empirical analysis.

\section{Literature Review and Hypothesis Development}

The information content of shareholder meetings can be considered one of the elements characterizing corporate governance (Di Toro, 2010; Busco \& Riccaboni, 2010). Several aspects of the annual shareholder meeting were analysed mainly in the U.S. context. Some research, based on market parameters, assessed the impact of the vote in shareholder meetings on the appointment of directors and their remuneration (e.g., Yermack, 2010). 
The annual meeting is conceived by corporate theory as a primary space for authentic and organic shareholder interaction with directors, management, and each other (Fairfax, 2013).

The annual shareholders meeting represents the main venue reserved for shareholders, particularly "a vibrant forum" for shareholder democracy even if its role is declining in the last decades. According to Nili and Shaner (2022) "Today's annual meetings are largely pro forma: only a handful of shareholders attend the meeting and voting results are largely determined in advance".

The "evasive" behaviour by company management at the shareholder meeting was indirectly observed by Li and Yermack (2016) through a study on the place of convening of the shareholder meeting; the results show that the convening of the shareholder meeting in places far from headquarters, in some way to discourage participation, is related with negative stock performance in the six months following the meeting.

A recent study (Nili \& Shaner, 2022) also highlights that the reasons for which shareholders' attendance is low are due to time and travel cost but also to concentration of annual meeting dates during the proxy season, to pro-forma nature of most annual meetings and to a reduction of the "perks" offered at the meeting (meals, etc.) (Feloni, 2017). Consequently, in most cases, annual meeting is attended by local retail and employee shareholders.

Even prior research, such as Kastiel and Nili (2016) show investor participation in voting has systematically declined over the past two decades, although technological, regulatory, and corporate governance changes tend to strengthen retail shareholder participation (Brochet et al 2021).

With regard to the possible relationship between participation in shareholder meetings and company performance, it can be argued that a high level of participation and greater debate lead to a greater weighing of business decisions, resulting in higher profitability. The basic assumption in this reasoning is that more people can make better decisions than individuals and that debate helps to improve decision-making. In this approach, it is suggested that shareholder participation in company decision-making processes should be increased (e.g., Bebchuk, 2005). However, this logic can be countered by the opposite argument, namely, that management has more information than shareholders to make decisions designed to achieve satisfactory economic performance (e.g., Bainbridge, 2006). In fact, empirical evidence from the U.S. confirms that, on average, $82.5 \%$ of votes in AGMs are in favour of management proposals and that, on average, these proposals are approved in $98.5 \%$ of the cases (Maug and Rydqvist, 2009).

Shareholder meetings can, however, be considered an "arena" in which the confrontation between majority and minority shareholders takes place (Poulsen et al., 2010). It is considered, in fact, that a greater degree of involvement of shareholders and, in particular, institutional investors in monitoring the work of directors can help to achieve higher levels of corporate performance. This is a different issue from the relationship between equity concentration and corporate performance, on which there is conflicting evidence, as summarized in the meta-analysis conducted by La Rocca et al. (2017).

In the Italian context, some empirical research carried out on institutional investors highlights among the monitoring and engagement tools with listed companies the participation in meetings. These behaviours have been observed in adherence to the "Italian stewardship principles for the exercise of administrative and voting rights in listed companies" (Assogestioni, 2016).

From the above, the direction of the relationship between participation in shareholder meetings and corporate profitability is not clear theoretically; therefore, our research question can be considered an empirical one. Consequently, we formulate our hypothesis in null form as follows:

H1 Participation at shareholder meetings is not related to corporate profitability.

\section{Empirical Research}

\subsection{Sample Selection}

The sample was selected starting from the Italian companies listed on the stock exchange on 29 December 2017, since we wanted to observe the characteristics of shareholder meetings in two years, 2017 and 2018, i.e., AGMs intended to adopt the financial statements relating to the fiscal periods 2016 and 2017. As shown in Table 1, firms operating in the banking, insurance and financial sectors and foreign companies were excluded according to the classification proposed in the statistics of Borsa Italiana (Italian Stock Exchange). A further refinement took place excluding cases where the minutes of the shareholders meeting were not available and/or did not report the start and end times of the AGM (ordinary meeting) compared to the extraordinary meetings, of companies that, although not classified foreign carried out the shareholder meetings abroad according to rules 
other than Italian company law, and for companies of which no financial data were available necessary for carrying out the analysis. For the 2017 fiscal period, 161 observations were available, and for the 2016 period, 151 observations were available, for a total of 312 company-year observations.

Table 1. Sample selection

\begin{tabular}{llll}
\hline & 2017 & 2016 & Total comments \\
\hline Listed companies (MTA) at 29/12/17 & 244 & N.a. & \\
Financial & $(55)$ & N.a. & \\
Foreign & $(4)$ & N.a. & \\
Suspended & $(1)$ & N.a. & $(18)$ \\
Missing minutes of AGM & $(14)$ & $(7)$ & \\
AGM held abroad & $(7)$ & $(8)$ & 312 \\
Missing financial data & $(2)$ & 151 & \\
Total & 161 & & \\
\hline
\end{tabular}

\subsection{Performance Variables}

Three different approaches can be used substantially when measuring business performance. The first refers mainly to accounting indicators (e.g., Muth, Donaldson, 1998; Erhardt et al., 2003); the second uses market indicators as a priority (e.g., Barhart, Rosenstein, 1998; Nicholson, Kiel, 2003); and the third uses a combination of these two (e.g., Thomsen, Pedersen, 2000; Evans et al., 2002). In this survey, to identify performance variables, we follow the first of the approaches, i.e., accounting indicators.

In particular, in the analysis of firm performance defined in terms of profitability, we gathered accounting information from the Aida database, referring to consolidated financial statements when drawn up. In particular, the indicators selected, as widely recognized in the literature as evidence of corporate profitability, are:

- return on equity (ROE) defined in the Aida database as the ratio of net profit to equity;

- return on assets (ROA) defined in the Aida database as the ratio of operating results to total assets.

To carry out a multivariate analysis, we selected other variables characterizing the companies under observation. In particular, the total assets capture the influence of corporate size (SIZE) and the debt-to-equity ratio (DEBT_E) to highlight the degree of financial risk. DEBT_E is defined in the Aida database as the ratio of financial debts (to banks and other lenders, both short and long term) and equity. Another variable is the number of days (N_DAYS) between the closing date of the fiscal period and the date of the AGM, which may indicate management problems in the case of an extension of the time beyond the ordinary deadlines provided for by law (120 days).

\subsection{Variables Related to Participation in the AGM}

To analyse the characteristics of the shareholder meetings to approximate the measure of shareholder participation, we used several variables acquired directly from reading the published AGM minutes. In particular, we selected the following variables:

- number of shareholders present at the shareholder meeting on their own or by proxy (N_SH);

- share of the authorized capital represented at the shareholder meeting (AC_IN);

- duration of the meeting expressed in hours and minutes in decimal form (DUR_A). With regard to this variable, to improve comparability, we have considered the duration of the ordinary shareholder meeting intended for the adoption of the financial statements, excluding the timing relating to any extraordinary shareholder meetings held on the same day. The collection of this information was acquired from the start time and closing time as written in the minutes of the shareholder meeting.

To consider the ownership structure of the companies analysed, we also considered the weight of the first three shareholders (SH1, SH2, SH3) holding shares of more than $3 \%$ or $5 \%$, depending on the disclosure rules established by Consob (Italian Securities and Exchange Commission).

Within the Italian regulatory framework discussed above, certain provisions can be considered tools to encourage shareholder participation in shareholder meetings. In particular, we considered a number of dummy variables: the formulation of questions before the meeting itself (ex article $127 \mathrm{~b}$ of the TUF) represented by the QUES variable, the presence of a designated representative (R_DES) ex art. 135-undicies of the TUF, the use of a voting mechanism by show of hands or different methods by means of automatic voter registration systems 
(V_AM), the presence of some form of limitation on the voting right L_VOT as a form of deviation from the principle of "one share one vote", and the presence of institutional investors at the shareholder meeting (INV_I). In addition, a series of dummy variables refer to the industrial sectors (IND) according to the Italian stock exchange classification. In particular, IND1 = utilities (public services); IND2 = telecommunication (telecommunications); IND3 = consumer goods; IND4 = industrials; IND5 = health care; IND6 = basic materials; IND7 = consumer services; IND8 = technology; and IND9 = oil \& gas (oil and natural gas). Finally, a series of dummy variables refer to the years 2017 and 2018 (YEAR) under observation.

\subsection{The Relationship between Corporate Profitability and Shareholder Meeting Participation}

To analyse the relationship between corporate profitability and participation in shareholder meetings, we carry out a multivariate analysis using a linear regression model (OLS). The model alternately has ROE and ROA as dependent variables, while among the independent variables, we selected some of those characteristics discussed earlier. In particular, for the purpose of relationship analysis, the model is as follows:

$$
\begin{gathered}
R O E(R O A)=b+b 1 N_{-} S H+b 2 A C \_I N+b 3 D U R \_A+b 4 S H 1+b 5 Q U E S+b 6 R_{-} D E S+b 7 V \_A M+b 8 \\
L_{-} V O T+b 9 I N V \_I+b 10 S I Z E+b 11 D E B T \_E+b 12 D A Y S+D \_I N D+D_{-} Y E A R+e
\end{gathered}
$$

The first three independent variables (b1 to b3) are expected to capture participation in shareholder meetings by means of the number of shareholders (N_SH), the share of authorized equity capital represented at shareholder meetings (AC_IN) and the duration of the AGMs (DUR_A). The fourth variable (b4) specifies the possible role played by the first shareholder (SH1). The variables from five to nine (b5 to b9) express different characteristics regarding the implementation of legislative instruments illustrating the way shareholders participate in AGMs, including questions expressed before the AGM (QUES), the appointment of designated representative (R_DES), the way in which shareholders vote (V_AM), any limitations or voting rights increase (L_VOT) and the presence of institutional investors (INV_I). The variables from ten to twelve (b10 to b12) denote some business characteristics in terms of size, total assets (SIZE), financial risk (DEBT_E) and time distance between the end of the fiscal period and the date of the AGM for the adoption of the annual financial statements (DAYS). This is followed by a series of dummy variables relating to the production sectors (D_IND) and the years under observation (D_YEAR).

\section{Results}

\subsection{Descriptive Statistics}

With regard to the performance variables, the data contained in Table 2 show that corporate profitability represented by ROE has an average value of 5.6\% (median 7.7\%). In addition, the number of observations for this variable was 305 , as in some cases, the value was not significant, for example, due to the presence of negative equity. In parallel, the other performance variable, ROA, shows an average value of $4.17 \%$ (median $4.48 \%$ ) and less variability than ROE.

\begin{tabular}{|c|c|c|c|c|c|c|c|c|}
\hline Variable & & Average & SD & Min & $1 \mathrm{Q}$ & $2 \mathrm{Q}$ & $3 \mathrm{Q}$ & Max \\
\hline N_SH & & 240 & 480 & 1 & 12 & 54 & 228 & 3.531 \\
\hline AC_IN & & 0,7007 & 0,1357 & 0,1886 & 0,6249 & 0,7280 & 0,7999 & 0,9557 \\
\hline DUR_A & & 1,68 & 1,40 & 0,20 & 0,85 & 1,33 & 2,00 & 12,00 \\
\hline SH1 & & 0,4817 & 0,1865 & 0,0501 & 0,3182 & 0,5281 & 0,6133 & 0,8999 \\
\hline $\mathrm{SH} 2$ & & 0,0868 & 0,0767 & 0 & 0,0401 & 0,0708 & 0,1256 & 0,3391 \\
\hline $\mathrm{SH} 3$ & & 0,0348 & 0.0498 & 0 & 0 & 0 & 0,0584 & 0,28 \\
\hline \multicolumn{9}{|l|}{$(\mathrm{N}=305)$} \\
\hline ROA (\%) & & 4,17 & 9,17 & $-83,75$ & 1,65 & 4,48 & 7,5 & 35,46 \\
\hline TA $(€ 000)$ & & 4.325 .099 & 16.917 .967 & 3.929 & 184.810 & 521.615 & 1.807 .683 & 155.641 .000 \\
\hline SIZE & & 20,23 & 1,8465 & 15,18 & 19,035 & 20,075 & 21,315 & 25,77 \\
\hline $\begin{array}{l}\text { DEBT_E } \\
(\mathrm{N}=309)\end{array}$ & & 0.8644 & 1,2452 & 0 & 0,2 & 0,51 & 0,99 & 10 \\
\hline DAYS & & 121 & 19,67 & 90 & 111 & 117 & 120 & 242 \\
\hline \multicolumn{9}{|c|}{ QUES (= 1), No. 129 (41\%) } \\
\hline \multicolumn{9}{|c|}{ R_DES (=1) N. $172(55 \%)$} \\
\hline V_AM $(=1$ & ง. 60 & $9 \%)$ & & & & & & \\
\hline
\end{tabular}

Table 2. Descriptive statistics of the variables used ( $\mathrm{N}=312$ firm-year observations) 


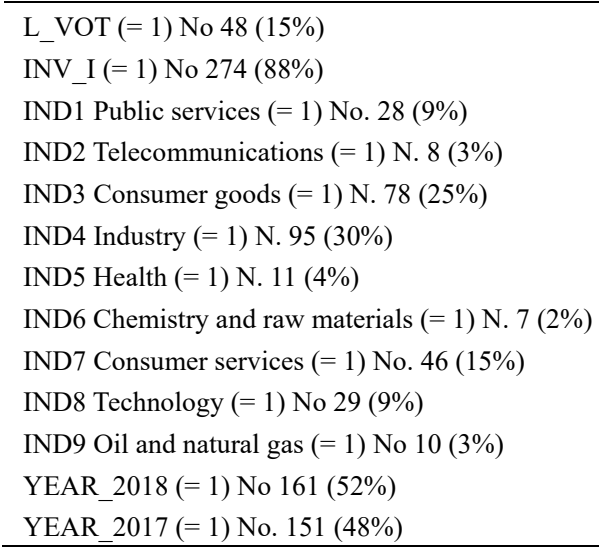

Notes. Definition of variables: N_SH = number of shareholders present on their own or by proxy at the shareholder meeting; AC_IN = share of the authorized capital represented at the shareholder meeting; DUR_A = duration of the AGM expressed in decimal hours and minutes; $\mathrm{SH} 1, \mathrm{SH} 2, \mathrm{SH} 3$ = share holdings of the first, second and third shareholders; $\mathrm{ROE}$ = ratio of net profit to equity expressed as a percentage; $\mathrm{ROA}=$ ratio of operating result to total assets expressed as a percentage; $\mathrm{TA}=$ total assets of the balance sheet; SIZE $=$ natural logarithm of TA; DEBT_E = ratio of debts to banks plus debts to other lenders and equity; DAYS = number of days between the closing date of the administrative period and the date of the meeting; QUES $=1$ if at least one shareholder has submitted questions before the shareholder meeting, otherwise $0 ; \mathrm{R} \_D E S=1$ if this representative is appointed, otherwise $0 ; V_{-} A M=1$ if $I$ vote in the assembly by automatic counting, otherwise (show of hands) $=0$; L_VOT $=1$ if there is a limitation or increase to the right to vote, otherwise 0 ; INV_I $=1$ if present on its own or by proxy at least one institutional investor in the shareholder meeting, otherwise $=0$; the IND and YEAR variables are self-explanatory.

From reading the 312 minutes of the shareholders meeting (average number of pages per minute is 26), information was collected on the main variables used in this study to capture the participation of shareholders. On average, the share of authorized equity capital attending the AGM (AC_IN) is approximately 70\% (median approximately $73 \%$ ). It can be assumed that the percentage of authorized equity capital not attending the shareholders' meeting (approximately 30\%) is somewhat attributable to "private investors" who, for various reasons, do not attend AGMs either on their own or by proxy. Statistical data regarding the AGMs of listed companies in the U.S. show that, on average, from 2016 to 2020 , approximately $72 \%$ of private shareholders do not attend and do not cast a vote at shareholder meetings; in contrast, this percentage drops to approximately $9 \%$ in the case of institutional investors. New regulatory "devices" and new technologies should make it possible to reduce this average rate of nonattendance through forms of remote involvement and webcasting. The variable denoting the number of shareholders (N_SH) shows an average of 240, with a median of 54. In fact, we observe minimum values of only one shareholder, and the first quartile is 12 . Therefore, the average is somewhat driven by the maximum values of the number of shareholders attending on their own or by proxy. On this variable, a key role could be played by proxy advisors, as shown in the European context by Hitz and Lehmann (2018). Institutional investors with highly diversified securities portfolios often turn to consulting firms to analyse the documents related to the AGM and receive voting recommendations. As a result, the influence of these consultants on the vote appears to be significant. According to some research (Assonime, 2012), institutional investors make more use of proxy advisors for investments in foreign companies than for investments in the domestic market. Therefore, the influence of such advisors is greater in markets with a high percentage of international investors.

Another parameter used to capture participation was identified in the duration of the AGM (DUR_A). The values in Table 2 are displayed in decimal hours (h). Therefore, the average value of 1.68 is equivalent to approximately one hour and forty minutes. The median is 1.33 (i.e., one hour and twenty minutes). The two extreme values are 12 minutes (minimum value) and 12 hours (maximum value). Longer duration implies, in some way, greater participation and discussion at the AGM by shareholders.

Turning to the ownership structure of the sample analysed, it can be seen that the average shareholding of the main shareholder (SH1) reveals a high share concentration in the Italian context with a value of approximately $48 \%$; adding up the first three shareholders ( $\mathrm{SH} 1+\mathrm{SH} 2+\mathrm{SH} 3)$ results in an average shareholding of approximately $60 \%$. This evidence indirectly confirms a certain degree of "stability" in terms of ownership structure to such an extent that "from an Anglo-Saxon perspective, no country more than Italy symbolizes family capitalism" (Aganin \& Volpi, 2003). Thus, compared with other capitalist systems, there is a limited separation 
between ownership and control; moreover, the largest shareholder exceeds $50 \%$ in 179 observations or $57 \%$ of the sample observed. It is therefore confirmed that in the Italian context, the main agency problem is between majority shareholders and minority shareholders.

Turning to the analysis of some characteristics of the use of regulatory instruments that should facilitate attending AGMs, we observe that the opportunity to ask questions about company management before the AGM date (QUES) takes place in approximately $41 \%$ of the meetings (129/312). The questions are, in fact, an expression of a culture of participation despite the risk the questions become an element of disturbance. The instrument of the designated representative (R_DES) (ex art. 135 of the TUF) appears formally used by the majority of the business units observed in the sample: 172 or $55 \%$ of the observations. However, the actual use of this instrument appears marginal; in fact, in only 27 cases out of the total of $172(16 \%)$ mandates was the designated representative given. This is most likely explained in the sense that the task of the designated representative is often in some way connected with the task of providing organizational services for the proper conduct of the shareholders meeting, while the function of the shareholder mandate remains unused.

The prevailing voting mode is by show of hands, used in 252 cases $(81 \%)$, indirectly showing that the number of people physically attending the shareholders meeting is a small number. In 60 cases (19\%), a form of voting by electronic means (remote control) was provided to attending shareholders before the start of the shareholder meeting. It should be pointed out that this is not electronic mail voting, which is largely absent from the sample examined. Therefore, this procedure was provided by Directive 2017/828/EU (Shareholders' Directive) and implemented in the Italian legislation (Legislative Decree No. 49/2019) with the aim of removing the obstacles that limit the possibility of shareholder intervention and that voting rights are not taken into account. However, our legislator has clearly specified how the vote expressed in electronic form (or rather, by means of telecommunications) must be automatically equated with postal voting (art. 2370, fourth paragraph, C.C.).

In this regard, the stock market regulator in Australia expressed concern at its 2017 meetings that 25 companies in the ASX 200 index continued to decide by a show-of-hand vote (ASIC, 2018). It should be noted that other means of participation and voting (for example, hybrid forms, in presence or online) could become more important in the future, particularly in light of the COVID-19 pandemic context since 2020. Indeed, as early as 2018, the Parliamentary Committee of Inquiry into the Banking and Financial System, in one of its final reports, proposed regulatory changes aimed at the live webcasting of AGMs (CP, 2018, p. 451).

Voting restrictions were observed in 48 cases $(15 \%)$ and can be traced back to voting or statutory provisions that include cases (D. L. 332/1994, as amended by Law 474/1994) in which the voting rights inherent in shares held in excess of the maximum shareholding limit (equal to $3 \%$ or $5 \%$ ) cannot be exercised. This phenomenon, therefore, appears to be contained and in theory, aims to strengthen the management power of shareholders who have held shareholdings for a long time (in the case of increased voting rights, according to Art. 127-quinquies TUF). The presence of institutional investor shareholders (INV_I) appears large; in fact, in 274 cases (88\%), at least one institutional investor was present at the shareholder meeting. This evidence seems consistent with the idea that, among the monitoring and engagement tools with listed companies, institutional investors comply with the "Italian stewardship principles for the exercise of administrative and voting rights in listed companies" for participation in AGMs (Assogestioni, 2016). The high attendance of institutional investors in this survey also confirms that these subjects represent important shareholders of listed companies and can, therefore, play an important role in corporate governance.

With regard to the company size indicated by the total assets (TA), there is wide variability in the observed sample. The average of total assets is 4.3 billion euros; however, the median is approximately 522 million euros. This figure is also indicated by the standard deviation (SD) and is an expression of the incidence of a few large companies in the distribution of this variable. With regard to the debt/equity ratio (DEB_E) proxy for financial risk, a value of 0.86 (median 0.51) is observed on average and indicates the important and traditional use of bank credit by Italian companies with respect to equity capital. There were 309 observations on this variable because in some cases, the calculation was not significant.

Finally, the date of the meeting for the adoption of the financial statements with respect to the closing date of the fiscal period is an indirect indicator of any management problems. Delays in relation to the deadlines established by the regulatory provisions may be an expression of difficulty. In the sample observed, the number of days (DAYS) between the end of the fiscal period and the date of the meeting was 121 (median 117), substantially in line with the ordinary deadlines provided for by current corporate law and in effect in the observation period (120 days) extendable to 180 days for particular needs and/or reasons.

Among the untabulated results, it should be noted that the location of AGMs coincides with the municipality or 
city where the listed companies have their headquarters. This evidence is in line with the provisions of the Civil Code (art. 2363) to convene shareholder meetings in the municipality where the company has its registered office unless otherwise provided by the Statute. Therefore, the phenomenon of choosing places that are difficult to reach compared to the company's headquarters is not observable, as, for example, shown by Li and Yermack (2016) in the U.S. Another untabulated result indicates the substantial not use of electronic or postal voting and the absence of requests for changes to the agenda or proposals for resolutions by shareholders ex art. 126-bis TUF.

\subsection{Discussion}

Table 3 shows the results of the multivariate analysis with reference to the ROE profitability variable. In this analysis, the number of observations was 303, since cases where this variable and DEBT_E were not significant (e.g., for negative equity) were dropped.

Compared to the three variables used to measure participation in shareholder meetings, the AC_IN variable $(p=0.0000)$ is highly significant. With a positive sign, the share of equity capital represented at shareholder meetings appears to be significantly associated with the corporate profitability expressed by the ROE. The other two variables are not significant. With reference to the hypothesis formulated on the relationship between profitability and participation in shareholder meetings, it can be said that there is evidence to support this relationship when shareholder participation is measured by the percentage of equity capital attending AGM and the performance variable is ROE.

Table 3. Regression (OLS) ROE

\begin{tabular}{|c|c|c|c|c|}
\hline & Coeff & $S E$ & $t$-stat & $p$ \\
\hline N_SH (b1) & $-0,0009$ & 0,003 & $-0,26$ & 0,794 \\
\hline AC_IN (b2) & 51.55 & 10.46 & 4.93 & 0,000 \\
\hline DUR_A(b3) & 0,9494 & 1.121 & 0,85 & 0,398 \\
\hline SH1 (b4) & $-14,41$ & 7,921 & $-1,82$ & 0,070 \\
\hline QUES (b5) & 2,428 & 2,605 & 0,93 & 0,352 \\
\hline R_DES (b6) & $-1,246$ & 2,450 & $-0,51$ & 0,611 \\
\hline V_AM (b7) & $-2,104$ & 3,592 & $-0,59$ & 0,558 \\
\hline L_VOT (b8) & 4,168 & 3,113 & 1,34 & 0,182 \\
\hline INV_I (b9) & 7,421 & 3,971 & 1,87 & 0,063 \\
\hline SIZE (b10) & 0,280 & 1,014 & 0,28 & 0,783 \\
\hline DEBT_E (b11) & $-2,643$ & 0,993 & $-2,66$ & 0,008 \\
\hline DAYS (b12) & $-0,264$ & 0,068 & $-3,87$ & 0,000 \\
\hline D_IND & \multicolumn{4}{|c|}{ Not reported } \\
\hline D_YEAR & \multicolumn{4}{|c|}{ Not reported } \\
\hline Constant (b0) & $-9,241$ & 21,82 & $-0,42$ & 0,672 \\
\hline
\end{tabular}

$\mathrm{N}=303 ; \mathrm{F}(21,281)=4.86 ;$ Probability $>\mathrm{F}=0.0000 ; \mathrm{R}$-squared $=0.2664 ;$ Adj R-squared $=0.2115$

Notes. Definition of variables: N SH = number of shareholders present on their own or by proxy at the shareholder meeting; AC IN = share of the authorized capital represented at the shareholder meeting; DUR_A = duration of the meeting expressed in hours and minutes in decimal form; $\mathrm{SH} 1=$ share holdings of the first shareholder; $\mathrm{ROE}=$ ratio of net profit to equity expressed as a percentage; SIZE $=$ natural logarithm of the active total; DEBT_E = ratio of debts to banks plus debts to other lenders and equity; DAYS = number of days between the closing date of the administrative period and the date of the meeting; QUES $=1$ if at least one shareholder has submitted applications before the shareholder meeting, otherwise $0 ; \mathrm{R} \_\mathrm{DES}=1$ if this representative is appointed, otherwise 0 ; V_AM $=1$ if $\mathrm{I}$ vote in the assembly by automatic counting, otherwise (show of hands) $=0 ; L_{-}$VOT $=1$ if there is a limitation or increase to the right to vote, otherwise 0 ; INV_I $=1$ if present on its own or by proxy at least one institutional investor in the shareholder meeting, otherwise $=0$; $\quad \mathrm{D}$ IND $=$ dummies variable for operating sectors as shown in Table 2, IND1 is the reference sector; D_YEAR = dummies variable for years as shown in Table 2, 2016 is the reference year.

Regarding the possible role of the first main shareholder (SH1), a negative and weakly significant coefficient $(p=0.0700)$ is observed. Further uncertainty is given by a confidence interval that also includes the positive sign of the same coefficient. Therefore, it does not appear possible to provide significant evidence on this point. 
Of the variables that characterize the AGM, the only variable that is significant is that relating to the attendance of institutional investors (INV_I). The coefficient is positive and weakly significant $(\mathrm{p}=0.063)$. Again, further uncertainty is given by a confidence interval of the coefficient that also includes the negative sign of the same coefficient.

Looking at the characteristics of the enterprises, the size of the firm does not appear relevant in terms of profitability. As expected, a high level of DEBT_E is negatively and significantly associated with profitability $(\mathrm{p}=0.008)$. In addition, the time gap between the closing date of the fiscal period and the date of the meeting was highly significant $(p=0.000)$. The coefficient is negative and shows that the lengthening of the time required for the adoption of financial statements is in some way linked to management problems and is negatively associated with company profitability.

The dummy variables linked to the industries show no statistical significance, except for the IND9 sector (oil and natural gas), which results in a positive coefficient. This result indicates greater profitability for this sector but should be interpreted with caution in view of the low number of companies operating in this sector within the sample observed. Finally, the dummy variable (YEAR) shows no effect on the company's profitability linked to one of the years under observation.

Table 4 shows the results of the multivariate analysis in the case of profitability measured by ROA. As pointed out in the previous analysis, here too, we observe a statistically significant and positive coefficient for the variable representing the percentage of equity capital attending AGMs (AC_IN). As in the analysis in terms of ROE, the other two variables (N_SH and DUR_A) are not significant.

Table 4. Regression (OLS) ROA

\begin{tabular}{|c|c|c|c|c|}
\hline & Coeff & $S E$ & $t$-stat & $p$ \\
\hline N_SH (b1) & 0,0011 & 0,0016 & 0,67 & 0,500 \\
\hline AC_IN (b2) & 20,49 & 4,73 & 4,33 & 0,000 \\
\hline DUR_A (b3) & $-0,566$ & 0,510 & $-1,11$ & 0,268 \\
\hline SH1 (b4) & $-5,709$ & 3,572 & $-1,60$ & 0,111 \\
\hline QUES (b5) & 0,557 & 1,181 & 0,47 & 0,637 \\
\hline R_DES (b6) & $-0,521$ & 1,104 & $-0,47$ & 0,637 \\
\hline V_AM (b7) & 0,626 & 1,634 & 0,38 & 0,702 \\
\hline L_VOT (b8) & 0,084 & 1,406 & 0,06 & 0,952 \\
\hline INV_I (b9) & 0,330 & 1,781 & 0,19 & 0,853 \\
\hline SIZE (b10) & 0,608 & 0,442 & 1,37 & 0,170 \\
\hline DEBT_E (b11) & $-0,650$ & 0,431 & $-1,51$ & 0,133 \\
\hline DAYS (b12) & $-0,067$ & 0,029 & $-2,28$ & 0,023 \\
\hline D_IND & \multicolumn{4}{|c|}{ Not reported } \\
\hline D_YEAR & \multicolumn{4}{|c|}{ Not reported } \\
\hline Constant (b0) & $-10,86$ & 9,720 & $-1,12$ & 0,264 \\
\hline $\mathrm{N}=309 ; \mathrm{F}(21$, & 140 & & & \\
\hline
\end{tabular}

Notes. Definition of variables: N_SH = number of shareholders present on their own or by proxy at the shareholder meeting; AC_IN $=$ share of the authorized capital represented at the shareholder meeting; DUR_A = duration of the meeting expressed in hours and minutes in decimal form; $\mathrm{SH} 1=$ share holdings of the first shareholder; ROA = ratio of operating result to total assets expressed as a percentage; $\mathrm{SIZE}=$ natural logarithm of the active total; DEBT_E = ratio of debts to banks plus debts to other lenders and equity; DAYS = number of days between the closing date of the administrative period and the date of the meeting; QUES = 1 if at least one shareholder has submitted applications before the shareholder meeting, otherwise $0 ; \mathrm{R} \_\mathrm{DES}=1$ if this representative is appointed, otherwise 0 ; V_AM $=1$ if $\mathrm{I}$ vote in the assembly by automatic counting, otherwise (show of hands) $=0$; L_VOT $=1$ if there is a limitation or increase to the right to vote, otherwise 0 ; INV_I = 1 if present on its own or by proxy at least one institutional investor in the shareholder meeting, otherwise $=0$; D_IND = dummies variable for operating sectors as shown in Table 2, IND1 is the reference sector; D_YEAR $=$ dummies variable for years as shown in Table 2, 2016 is the reference year.

Doubts about the role of the main shareholder are confirmed in the analysis of the relationship with ROA where the variable SH1 is not significant. In the context of the elements that characterize some aspects related to the 
conduct of the meeting, none of the variables is significant, as already highlighted in the analysis of the effects on ROE. In particular, the weak role of INV_I in the ROE analysis is confirmed here with non-significance.

Looking at the characteristics of the companies, size does not appear relevant in terms of profitability expressed by ROA. In this case, the level of DEBT_E is not significant. This evidence can be interpreted as meaning that ROA suffers less from the financial structure and that the most significant impact of the DEBT_E is observable on net profitability. As in the previous analysis, the time gap between the closing date of the fiscal period and the date of the meeting was significant ( $p=0.023$ ). The coefficient is negative and corroborates that the lengthening of the time required for the adoption of financial statements is in some way suggestive of management problems and is negatively associated with company profitability.

The dummy variables related to industries and the years under observation show no statistical significance in terms of the effects on company profitability measured by ROA.

Overall, the multivariate analysis of the relationship between corporate profitability and participation in shareholder meetings shows that a high level of participation indicated by the percentage of equity capital attending AGM is positively associated with corporate profitability assessed with both ROE and ROA. This evidence can be interpreted in the sense that a virtuous circle in the relationship between companies and shareholders can lead to greater participation and better business results. However, the other variables used to capture participation in shareholder meetings were not significant.

Among the other variables used in the survey, it should be highlighted that the time gap between the closing date of the fiscal period and the date of the shareholders' meeting is negatively associated with firm performance.

\section{Conclusions}

The analysis shows that a high level of shareholder meeting participation, assessed by the percentage of equity capital attending AGMs, is somewhat positively associated with corporate profitability (ROE and ROA). Our evidence is descriptive by nature, as it is not possible to provide specific indications of a causal relationship. However, our research supports the idea that European policy-makers increase shareholder participation in the corporate management of listed companies (Shareholders' Directive, 2017). In essence, an institutional framework should be prepared that allows each shareholder, even if holding few shares, to participate and express the voting right on his own or by proxy (either personally or by proxy). Even in the Italian context characterized by high ownership concentration, greater participation in AGMs seems to be an element associated with better company results and may perhaps also be an indirect indication of greater dialogue between majority and minority shareholders.

At the same time, the sample noted that legislative instruments were used to participate in AGMs. Among the results not subject to systematic observation, the absence of the internet to facilitate participation and the relationship between shareholders and management at shareholder meetings are highlighted. Therefore, the use of the internet to vote in meetings (webcasting) is completely absent, while cases of electronic and postal voting are very rare.

AGMs held in hybrid form (in-presence and online) or virtual form could be instrumental in achieving greater shareholder participation, although they require technical and regulatory changes aimed at greater use of technology (e.g., Moriarty, 2018). In fact, these tools have found an opportunity to be used, at least on regulatory matters, in the context of the COVID-19 pandemic since 2020 and could be investigated in future research.

\section{References}

Aganin, A., \& Volpin, P. (2003). History of corporate ownership in Italy. NBER Working Paper.

ASIC. (2018). Report 564 Annual general meeting season 2017. Australian Securities \& Investments Commission.

Assogestioni. (2016). Principi italiani di stewardship per l'esercizio dei diritti amministrativi e di voto nelle società quotate.

Assonime. (2012). Le assemblee delle società quotate: il d.lgs. $n$. 27 del 27 gennaio 2010, le prime esperienze applicative nel 2011 e il decreto correttivo del 2012 (d.lgs. n. 91 del 18 giugno 2012). Note e Sudi, n.14.

Bainbridge, S. M. (2006). Director Primacy and Shareholder Disempowerment. Harvard Law Review, 119, 1735-1758.

Barnhart, S. W., \& Rosenstein, S. (1998). Board composition, managerial ownership, and firm performance: An empirical analysis, Financial Review, 33(4), 1-16. 
Bebchuk, Lucian A. (2005). The Case for Increasing Shareholder Power. Harvard Law Review, 118(3), 833-914.

Berle, A. A., \& Means, G. C. (1933). The Modern Corporation and Private Property. Macmillan Co, New York.

Bianchi, M., Bianco, M., \& Enriques, L. (2002). Pyramidal groups and the separation between ownership and control in Italy. In F. Barca and M. Becht (Eds.), The Control of Corporate Europe. Oxford University Press, Oxford, UK.

Broadridge. (2020). ProxyPulse - 2020 Proxy Season Review, Broadridge Investor Communication Solutions, Inc. and Pricewaterhouse Cooper LLP.

Brochet, F., Chychyla, R., \& Ferri, F. (2021). Virtual Shareholder Meetings. University of Miami Legal Studies Research Paper No. 3743064, European Corporate Governance Institute - Finance Working Paper No. $777 / 2021$.

Busco, C., \& Riccaboni, A. (2010). Governo e gestione delle performance d'impresa. Pearson Education.

Catturi, G. (2019). Principi di Economia Aziendale. Wolters Kluwer Cedam, sesta edizione.

Commissione, P. (2018). Relazione Finale Commissione parlamentare d'inchiesta sul sistema bancario e finanziario, Camera dei Deputati e Senato della Repubblica.

Di Toro, P. (2010). Corporate Governance. Principi di comportamento per il governo delle società di capitali. Il Sole 24 Ore.

Dunlavy, C. A. (2006). Social Conceptions of the Corporation: Insights from the History of Shareholder Voting Rights. Washington and Lee Law Review, 63(4), 1354-1356.

Erhardt, N. L., Werbel, J. D., \& Shrader, C. B. (2003). Board of director diversity and firm financial performance. Corporate Governance: An International Review, 11, 102-111. https://doi.org/10.1111/1467-8683.00011

Evans, J., Evans, R., \& Loh, S. (2002). Corporate governance and declining firm performance. International Journal of Business Studies, 10(1), 1-18.

Fairfax, L. (2013). Mandating Board-Shareholder Engagement? University of Illinois Law Review, 821-857.

Feloni R., (2017). Here's what it's like to attend Walmart's 14,000-person shareholders meeting, a 3-day extravaganza. Business Insider. Retrieved from https://www.businessinsider.com/walmart-shareholders-meeting-2016-photos-2017-5

Hitz, Joerg-Markus, \& Lehmann, N. (2018). Empirical Evidence on the Role of Proxy Advisors in European Capital Markets. European Accounting Review, 27(4), 713-745. https://doi.org/10.1080/09638180.2017.1305282

Kastiel, K., \& Yaron N. (2016). In Search of the "Absent" Shareholders: A New Solution to Retail Investors' Apathy. Delaware Journal of Corporate Law, 41, 55-104.

Kiel, G. C., \& Nicholson, G. J. (2003). Board composition and corporate performance: How the Australian experience informs contrasting theories of corporate governance. Corporate Governance: An International Review, 11, 189-205.

La Rocca, M., Montalto, F., La Rocca, T., \& Staglianò, R. (2017). The effect of ownership on firm value: a meta-analysis. Economics Bullettin, 37, 2324-2353.

Li, Y., \& Yermack, D. (2016). Evasive shareholder meetings. Journal of Corporate Finance, 38, 318-334,

Maug, E., \& Rydqvist, K. (2009). Do Shareholders Vote Strategically? Voting Behavior, Proposal Screening, and Majority Rules. European Finance Review, 13(1), 47-79. https://doi.org/10.1093/rof/rfn026

Moriarty, R., Halstead, R., \& Sharma, S. (2018). ASIC highlights the importance of annual general meetings and recent trends in corporate governance, Governance Directions, 77-79.

Muth, M., \& Donaldson, L. (1998). «Stewardship theory and board structure: A contingency approach», Corporate Governance: An International Review, 6(1), 5-28. http://dx.doi.org/10.1111/1467-8683.00076

Nili, Y., \& M. W. Shaner. (2022). Virtual Annual Meetings: A Path Toward Shareholder Democracy and Stakeholder Engagement. Boston College Law Review, 63(1).

Poulsen, T., Strand, T., \& Thomsen, S. (2010). Voting power and shareholder activism: A study of Swedish shareholder meetings. Corporate Governance: An International Review, 18(4), 329-343. https://doi.org/10.1111/j.1467-8683.2010.00811.x 
The Economist (2005). What shareholder democracy? March $26^{\text {th }}$.

The Economist (2017). Snap's IPO is part of a wider trend towards corporate autocracy, February $11^{\text {th }}$.

Thomsen, S., \& Pedersen, T. (2000). Ownership structure and economic performance in the largest European $\begin{array}{lllll}\text { companies. } & \text { Strategic } & \text { Management }\end{array}$ https://doi.org/10.1002/(SICI)1097-0266(200006)21:63.0.CO;2-Y

Yermack, D. (2010). Shareholder voting and corporate governance. Annual Review of Financial Economics, 2, $103-125$.

\section{Copyrights}

Copyright for this article is retained by the author(s), with first publication rights granted to the journal.

This is an open-access article distributed under the terms and conditions of the Creative Commons Attribution license (http://creativecommons.org/licenses/by/4.0/). 